\title{
THE ROLE OF BESTATIN, AN INHIBITOR OF CELL SURFACE PROTEASES, IN THE INTERACTION OF SERUM WITH UNTRANSFORMED CELLS IN CULTURE
}

\author{
Ruth Koren, Hedva Bercovitz, Hamao Umezawa* \\ and Werner E. G. Müller** \\ Department of Pharmacology, The Hebrew University Hadassah Medical School, Jerusalem, Israel \\ *Institute of Microbial Chemistry, Shinagawa-ku, Tokyo, Japan \\ **Institut für Physiologische Chemie, Abteilung “Angewandte Molekularbiologie”, \\ Universität, Duesbergweg, 65 Mainz, West Germany
}

(Received for publication October 24, 1980)

\begin{abstract}
Bestatin is an inhibitor of cell surface-associated aminopeptidase B and leucine aminopeptidase. This microbial product simulates the role of serum as an activator of uridine uptake in quiescent BHK cells. The compound significantly stimulates the incorporation of labelled thymidine into the acid-insoluble fraction of serum-starved Nil 8 cells in the presence of low concentration of serum. The possible mechanisms of these interactions are discussed.
\end{abstract}

Recent studies had revealed the fact that several exopeptidases are associated with the outer membrane of cells from various origins ${ }^{11}$. The biological role of these enzymes has not been elucidated. A series of compounds of microbial origin were isolated and purified by UMEZAWA et al. ${ }^{2}$, and found to inhibit the activity of some of these cell surface-associated proteases ${ }^{2,3)}$. Among these inhibitors, bestatin, [(2S, 3R)-3-amino-2-hydroxy-4-phenylbutanoyl]-L-leucine, has been studied in greatest detail. Bestatin is an inhibitor of aminopeptidase B and leucine aminopeptidase ${ }^{4)}$. The mode of inhibition was found to be competitive with respect to the substrate ${ }^{3)}$; the $K i$ was found to be around $10^{-8} \mathrm{M}^{3)}$. It has been found that bestatin stimulates DNA synthesis in T-type lymphocytes both in vivo, ${ }^{3,5)}$ and in vitro ${ }^{8,7)}$; the concentration range for these effects was shown to be in the order of $100 \mu \mathrm{M}$. It is not known whether the stimulatory influence of bestatin is due to the specific inhibition of aminopeptidases or to stimulation of some other biological activity in the lymphocyte ${ }^{6}$.

Untransformed cells growing in a monolayer reduce their multiplication rate after the cells become "confluent". This phenomenon has been called "density dependent inhibition of growth" or "contact inhibition of growth" ${ }^{8,9)}$. Many mammalian cells also stop growing when the culture medium is depleted of growth factors. Such cells are arrested in the $\mathrm{G}_{1} / \mathrm{G}_{0}$ or $A$ state of the cell cycle ${ }^{10,11)}$. Both density inhibited and growth factor depleted cells are stimulated to synthesize DNA and proliferate when fresh serum ${ }^{12,13,14)}$ or purified growth factors (review: Reference 15) are supplied.

The correlation between the uptake rate of uridine and the rate of growth of untransformed cells in culture is an established phenomenon (review: Reference 16). The rate of uridine uptake decreases as cells reach confluency and is one of the first processes to be activated after the addition of fresh serum to quiescent cultures ${ }^{16)}$.

Due to the fact that the existence of cell surface proteases seems to be a general phenomenon ${ }^{12}$, and the evidence of the "mitogenic-like" effect of the specific protease inhibitor bestatin ${ }^{5,8)}$ it was intriguing to look for its possible role in the growth regulation of untransformed cells in culture. This was done by assaying both uridine uptake and thymidine incorporation into DNA. 


\section{Materials and Methods}

\section{Cell culture}

Nil-8 and BHK cell cultures were restarted every 6 weeks from frozen stocks. The cells were grown and maintained in DulbecCo's modified EAGLE's medium (DMEM) to which $10 \%$ new born calf serum, antibiotics and glutamine (Bio-Lab Jerusalem) had been added. The cells were grown at $37^{\circ} \mathrm{C}$ in a $\mathrm{CO}_{2}$ enriched humidified atmosphere on $90 \mathrm{~mm}$ plastic petri dishes (Nunc, Denmark) and subcultured twice weekly at a density of $5 \times 10^{5}$ cells $/ 90 \mathrm{~mm}$ dish. For uptake and incorporation experiments cells were subcultured in $35 \mathrm{~mm}$ dishes at a density of approximately $10^{5}$ cells/dish.

Quiescent BHK cells for the uridine uptake experiments were prepared in the following manner:

Medium was replaced $2 \sim 3$ days after seeding by a medium containing $0.25 \%$ serum; the experiments were performed 72 96 hours after medium change. Serum-starved Nil 8 and BHK cells were seeded at a similar density and propagated for $3 \sim 4$ days at $10 \%$ serum. Twenty four hours prior to the experiment, medium was replaced by serum free DMEM. At confluency, the cells reach a density of approximately $10^{6}$ cells $/ 35 \mathrm{~mm}$ dish.

Uridine uptake experiments

Prior to the uptake experiments culture medium was sucked off and the cells were washed in PBS (phosphate buffered saline) containing $\mathrm{NaCl}, 8 \mathrm{~g}$ /liter; $\mathrm{KCl} 0.2 \mathrm{~g} /$ liter; $\mathrm{Na}_{2} \mathrm{HPO}_{4} \cdot 12 \mathrm{H}_{2} \mathrm{O}, 2.9 \mathrm{~g} /$ liter; $\mathrm{KH}_{2} \mathrm{PO}_{4}, 0.2 \mathrm{~g}$ /liter; $0.5 \mathrm{~mm} \mathrm{MgCl}_{2}$ and $0.7 \mathrm{~mm} \mathrm{CaCl}{ }_{2} ; \mathrm{pH}$ 7.4. Uptake of $5 \mu \mathrm{M}\left[{ }^{3} \mathrm{H}\right.$ ] uridine was followed as previously described ${ }^{17}$. Briefly, cells were exposed to $0.5 \mathrm{ml}$ of labelled uridine (Israel Nuclear Research Centre, Negev) solution $(0.5 \mu \mathrm{Ci} / \mathrm{ml})$ and placed on an enamel tray into a $33^{\circ} \mathrm{C}$ water bath for the desired time period. Uptake was terminated by 5 quick washes in ice cold PBS. $0.75 \mathrm{ml}$ of cold trichloroacetic acid (TCA) was added to the dish and acid-soluble material extracted at $4^{\circ} \mathrm{C}$ for 20 minutes; $0.5 \mathrm{ml}$ of the TCA extract was used for scintillation counting in a Triton based scintillation fluid.

Incorporation of labelled thymidine into acid insoluble fractions

Cells were exposed to a solution of $1 \mu \mathrm{M}\left[{ }^{3} \mathrm{H}\right]$ thymidine $(0.25 \mu \mathrm{Ci} / \mathrm{ml})$ in DMEM for 24 hours at $37^{\circ} \mathrm{C}$ in a $\mathrm{CO}_{2}$ enriched humidified atmosphere. Uptake was then terminated as in the uridine uptake experiments. After 20 minutes extraction with TCA, the residue was washed twice with TCA once with ethanol and acid insoluble fractions were extracted in $0.6 \mathrm{ml}$ of $0.5 \mathrm{M} \mathrm{KOH}$ for 30 minutes at room temperature. $0.4 \mathrm{ml}$ was taken for scintillation counting.

Bestatin was isolated from a fermentation broth of Streptomyces olivoreticuli and determined to be chromatographically pure ${ }^{18)}$.

\section{Results}

The effect of bestatin on the rate of uridine uptake by quiescent BHK cells is shown in Fig. 1. Quiescent cells were incubated for 90 minutes at $37^{\circ} \mathrm{C}$ in DMEM in presence or absence of $10 \%$ serum and/or $10 \mathrm{~nm}$ bestatin. Uptake of $5 \mu \mathrm{M}$ uridine was assayed subsequently in phosphate buffered saline (PBS). It is apparent that bestatin, at a concentration of $10 \mathrm{~nm}$, exerts the same effect on the rate of uridine uptake as do the effectors present in growth medium containing $10 \%$ fresh serum. The effects of serum and bestatin are not additive, indicating that the same "activated" state is reached as a result of bestatin or serum action.

Fig. 2 shows the results of an experiment in which the activation and uptake of uridine were assayed simultaneously. Quiescent BHK cells were exposed to PBS containing $5 \mu \mathrm{M}\left[{ }^{3} \mathrm{H}\right]$ uridine in presence or absence of $50 \mathrm{~nm}$ bestatin. As exposure to the labelled nucleoside and the activator occurred at the same time, the time course of the activation process could be assayed directly. The effect of bestatin is easily detectable after 10-minute incubation, indeed, a least square analysis of the data revealed no lag time in the action of bestatin on the uridine uptake system of BHK cells (a lag time in the order of $1 \sim 5$ minutes could not be detected in this experiment). 
Fig. 1. The effect of bestatin on the uptake of uridine by quiescent and serum activated BHK cells. Radioactivity (cpm/assay) accumulated in acid soluble pools of serum treated and untreated cells. A: Experiment carried out in absence of bestatin. B: Experiment carried out in presence of $10 \mathrm{~nm}$ bestatin. (1,000 cpm is equivalent to $15 \mathrm{pmol} / \mathrm{assay}$ dish).

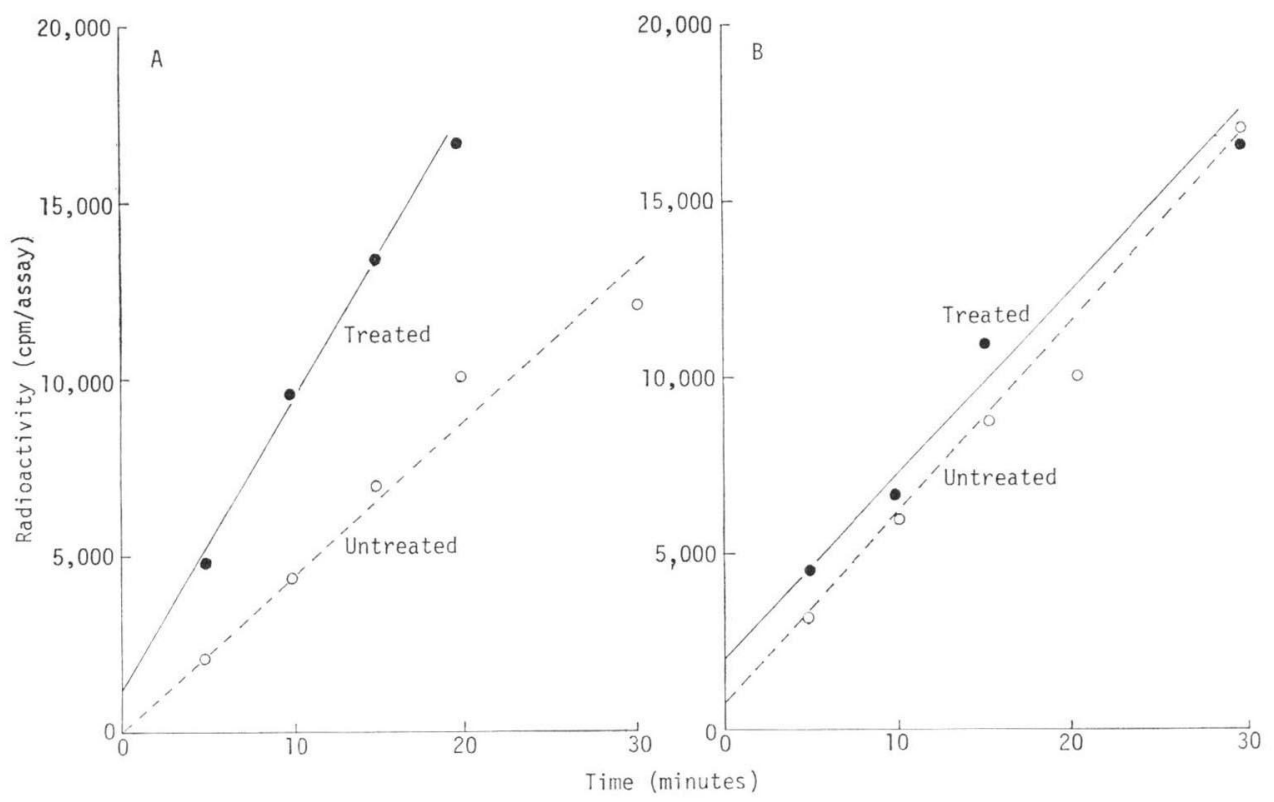

Fig. 2. The time course of activation of uridine uptake into quiescent BHK cells by bestatin.

Radioactivity (cpm/assay) accumulated in acid soluble pools in presence and absence of $50 \mathrm{~nm}$ bestatin. (1,000 cpm is equivalent to $15 \mathrm{pmol} / \mathrm{assay}$ dish).

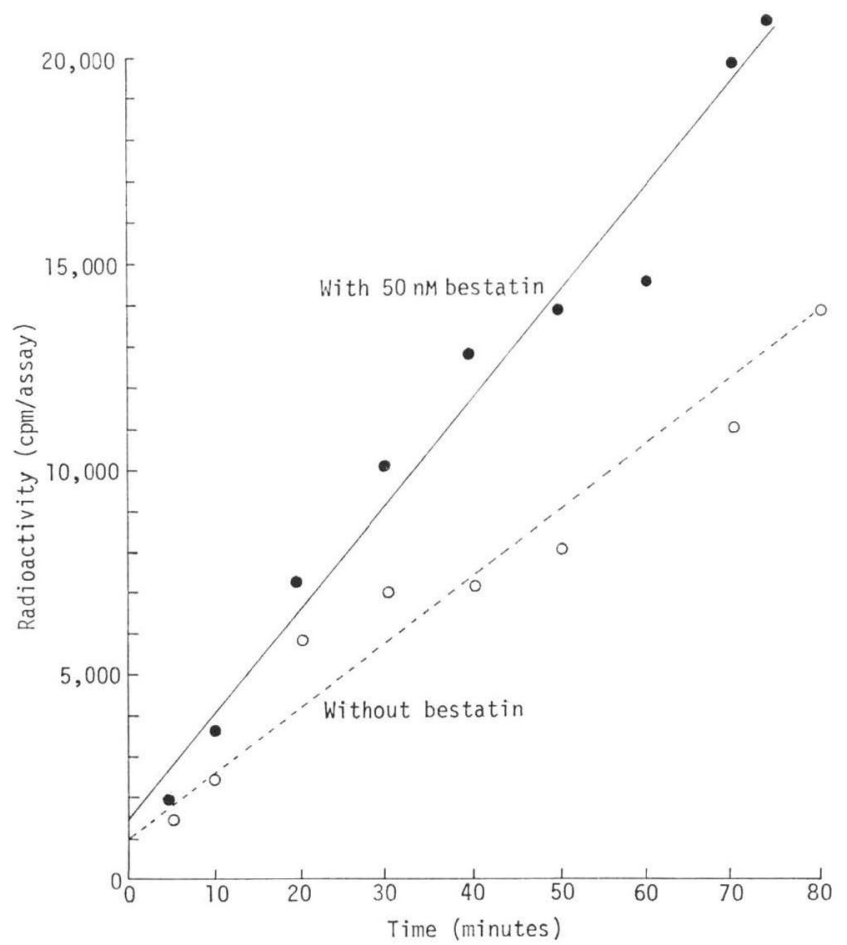


Fig. 3. The effect of bestatin and serum on the incorporation of thymidine into acid insoluble fractions of serum starved Nil 8 cells.

A: $[$ Bestatin $]=0.0 ; \mathrm{B}$ : $[$ Bestatin $]=10^{-7} \mathrm{M} ; \mathrm{C}$ : $[$ Bestatin $]=10^{-6} \mathrm{M} ; \mathrm{D}:[$ Bestatin $]=5 \times 10^{-6} \mathrm{M}$. $(1,000 \mathrm{cpm}$ are equivalent to $15.7 \mathrm{pmol} /$ assay $)$.

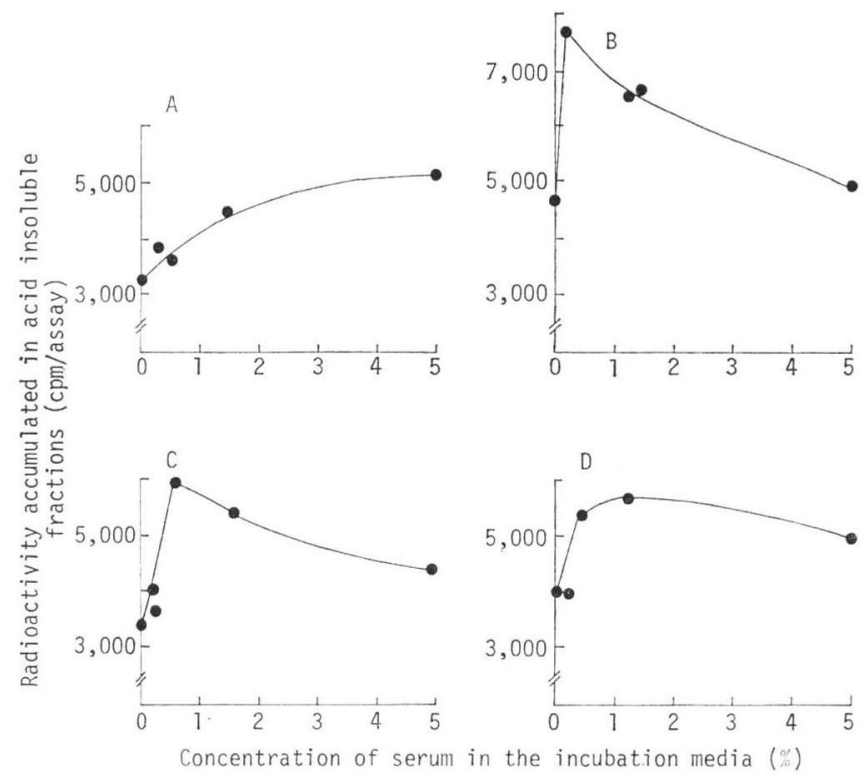

Fig. 3 shows the results of a 24-hour exposure of serum-starved Nil 8 cells to bestatin and labelled thymidine. The incorporation of $\left[{ }^{3} \mathrm{H}\right]$ thymidine into acid insoluble fractions increased significantly in those cells which were exposed to bestatin. The effect of bestatin is most striking in the presence of low concentration of serum. The stimulating effect of bestatin is most apparent in the presence of low concentrations of serum. The stimulating effect decreases as the concentration of either serum or bestatin increases, indicating a possible involvement of more than 1 site for bestatin.

A similar pattern is observed with BHK cells. Serum-starved cells were exposed for 24 hours to a solution containing $1 \mu \mathrm{M}\left[{ }^{3} \mathrm{H}\right]$ thymidine, serum and/or bestatin. In the absence of either serum or bestatin the incorporation of thymidine into acid insoluble fractions was $30 \pm 1 \mathrm{pmol} /$ assay; in presence of $10^{-6} \mathrm{M}$ bestatin the incorporation was: $38 \pm 1 \mathrm{pmol} /$ assay. This stimulation was eliminated in presence of $5 \%$ serum. The incorporation in the presence of $5 \%$ serum was $46 \pm 1 \mathrm{pmol} /$ assay, but when bestatin at the concentration of $10^{-7} \mathrm{M}$ was added to the same incubation medium incorporation increased to $55 \pm 0.5 \mathrm{pmol} /$ assay. As stated above this enhanced incorporation was eliminated when the bestatin concentration was increased to $10^{-8} \mathrm{M}$.

\section{Discussion}

We have been able to show that bestatin completely simulates the role of serum as an activator of uridine uptake into quiescent BHK cells. This effect in intact cells occurs at the same concentration range $(10 \mathrm{nM})$ as was reported to be the effective inhibitory concentration of protease in isolated form ${ }^{4)}$. Although this cannot be considered as a direct proof it is least possible that cell membrane proteases are involved at the initial phase of interaction between serum growth factors and quiescent cells.

After 24-hour incubation, bestatin at a concentration of $10^{-7} \mathrm{M}$ potentiates the effect of serum on DNA synthesis in serum-starved cells. This effect does not occur at high bestatin and/or serum 
concentrations. It would seem that bestatin exerts its effect only in a limited concentration range in the presence of low concentrations of serum. It is well established that externally added proteases have a stimulatory effect on confluent cells ${ }^{19,20)}$. The results reported here may indicate the presence of a cells surface-associated protease that has to be inhibited when cells are stimulated to grow. On the other hand it cannot be ruled out that bestatin acts directly upon a membrane receptor of a serum growth factor in a mechanism which is distinct from its action as an enzyme inhibitor. Investigation of the molecular nature of the interaction between bestatin and cell surface proteases should enable us to distinguish between these two mechanisms.

This work was supported by the Bundesministerium für Forschung und Technologie (BCT-8). The authors wish to thank Dr. W. D. SteIN (Hebrew University, Jerusalem) for valuable discussions.

\section{References}

1) Aoyagi, T.; H. Suda, M. Nagai, K. Ogawa, J. Suzuki, T. Takeuchi \& H. Umezawa: Aminopeptidases activities on the surface of mammalian cells. Biochim. Biophys. Acta 452: 131 143, 1976

2) Aoyagi, T. \& H. Umezawa: Structures and activities of protease inhibitors of microbial origin. In: Proteases and biological control (E. Reich, D. B. Rifkin \& E. Shaw, Eds.). pp. 429 454, Cold Spring Harbor Laboratory, Cold Spring Harbor, 1975

3) Umezawa, H.: Protease inhibitors produced by microorganisms. Acta Biol. Med. Germ. 36: 1899 1915, 1977

4) Nishizawa, R.; T. Saino, T. Takita, H. Suda, T. Aoyagi \& H. Umezawa: Synthesis and structureactivity relationships of bestatin analogues, inhibitors of aminopeptidase B. J. Med. Chem. 20: 510 515, 1977

5) Müller, W. E. G.; R. K. Zahn, J. Arendes, N. Munsch \& H. UmeZawa: Activation of DNA metabolism in T-cells by bestatin. Biochem. Pharmacol. 28: 3131 3137, 1979

6) Saito, M.; T. Aoyagi, H. Umezawa \& Y. Nagai: Bestatin, a new specific inhibitor of aminopeptidases, enhances activation of small lymphocytes by concanavalin A. Biochem. Biophys. Res. Commun. 76: 526 533,1977

7) MÜLLER, W.E. G.: Effects of microbial products on nuclear DNA-synthesizing enzyme systems. In: Effects of drugs on the cell nucleus (H. Busch, S. T. Crooke \& Y. DaSkal, Eds.), pp. $161 \sim 179$, Academic Press, New York, 1979

8) Aвеrсrombie, M.: Contact-dependent behaviour of normal cells and the possible significance of surface changes in virus-induced transformation. Cold Spring Harbor Symp. Quant. Biol. 27: 427 431, 1962

9) Stocker, M. G. P. \& H. Rubin: Density dependent inhibition of cell growth in culture. Nature 215: $171 \sim 172,1967$

10) Burns, F. J. \& J. F. Tannock: Density dependent inhibition of cell growth in culture. Cell \& Tissue Kinet. 3: $321 \sim 334,1970$

11) Smith, J. A. \& L. Martin: Do cells cycle? Proc. Natl. Acad. Sci., U.S.A. 70: 1263 1267, 1973

12) Todaro, G. Y.; D. Matsuya, A. Bloom \& H. Green: Growth regulating substances for animal cells in culture (V. DefENDI \& M. Stocker, Eds.). pp. 87 95, Wistar Institute Symposium Monograph, Vol. 7, Wistar Institute Press, Philadelphia, 1967

13) Pardee, A. B.: A restriction point for control of normal animal cell proliferation. Proc. Natl. Acad. Sci., U.S.A. $71: 1286 \sim 1290,1974$

14) Holley, R. W.: Control of growth of mammalian cells in cell culture. Nature 258: 487 490, 1975

15) Rudland, P. S. \& L. Jimenez de asua: Action of growth factors in the cell cycle. Biochem. Biophys. Acta 560: $91 \sim 133,1979$

16) KoREn, R.: The relevance of the state of growth and transformation of cells to their patterns of metabolite uptake. In: International review of cytology (G. H. Bourne \& J. F. Danielli, Eds.), in press, Academic Press, New York, 1980

17) Heichal, O.; D. Ish-shalon, R. Koren \& W. D. Stein: The kinetic dissection of transport from metabolic trapping during substrate uptake by intact cells. Biochim. Biophys. Acta 551: 169 186, 1979

18) Umezawa, H.; T. Aoyagi, H. Suda, M. Hamada \& T. Takeuchi: Bestatin, an inhibitor of aminopeptidase B produced by actinomycetes. J. Antibiotics 29: 97 99, 1976

19) Schnebli, H. P. \& M. M. Burger: Selective inhibition of growth of transformed cells by protease inhibitors. Proc. Nat1. Acad. Sci., U.S.A. 69: 3825 3827, 1972

20) Gospodarowicz, D. \& J. S. Moran: Growth factors in mammalian cell culture. Ann. Rev. Biochem. 45: 531 558, 1976 